WHITE PAPER

\title{
Quality Assurance Program Application for the Component Test Capability
}

Stephanie L. Austad

June 2009
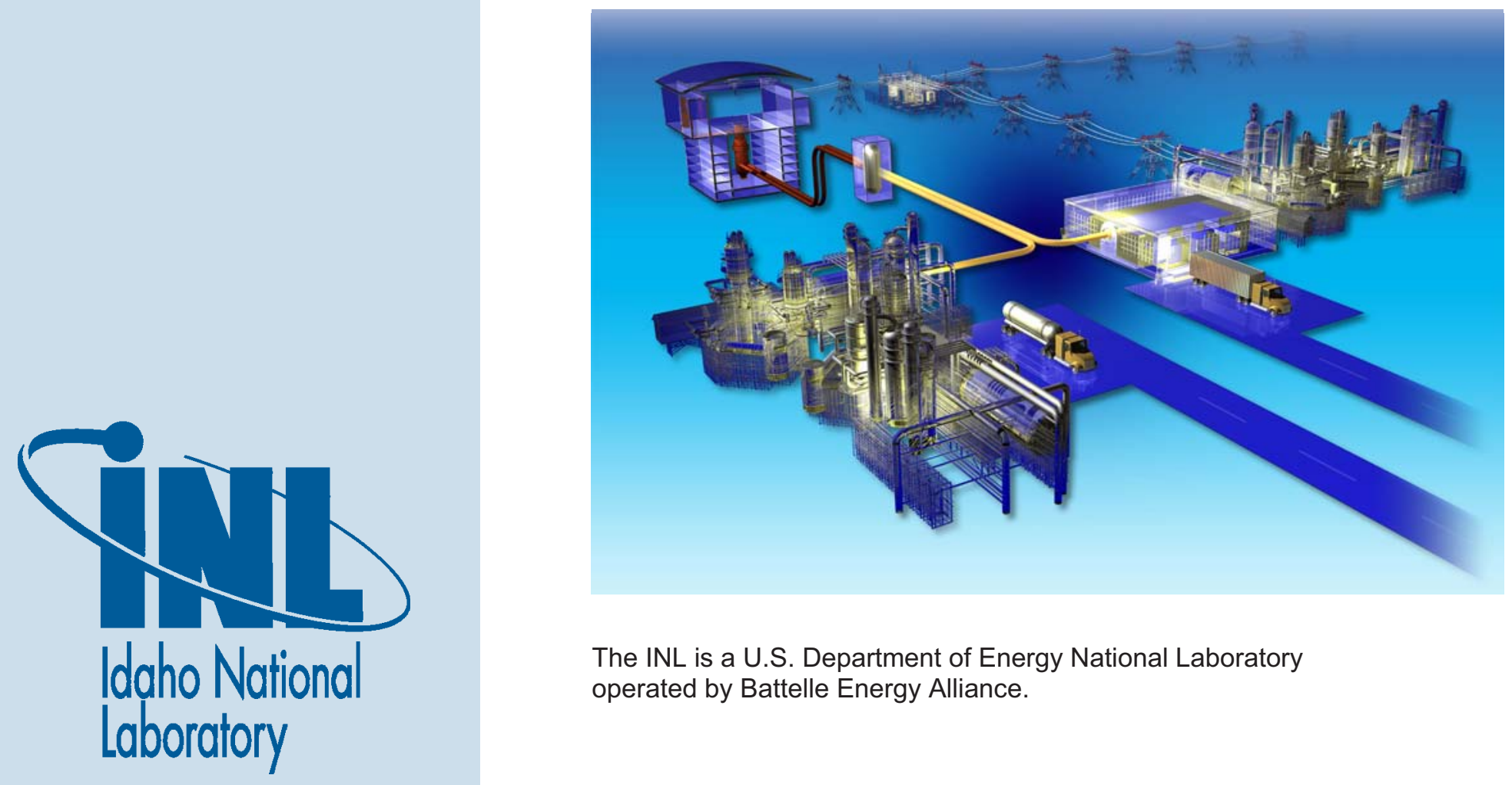

The INL is a U.S. Department of Energy National Laboratory operated by Battelle Energy Alliance. 


\section{DISCLAIMER}

This information was prepared as an account of work sponsored by an agency of the U.S. Government. Neither the U.S. Government nor any agency thereof, nor any of their employees, makes any warranty, expressed or implied, or assumes any legal liability or responsibility for the accuracy, completeness, or usefulness, of any information, apparatus, product, or process disclosed, or represents that its use would not infringe privately owned rights. References herein to any specific commercial product, process, or service by trade name, trade mark, manufacturer, or otherwise, does not necessarily constitute or imply its endorsement, recommendation, or favoring by the U.S. Government or any agency thereof. The views and opinions of authors expressed herein do not necessarily state or reflect those of the U.S. Government or any agency thereof. 
WHITE PAPER

\title{
Quality Assurance Program Application for the Component Test Capability
}

\author{
Stephanie L. Austad
}

June 2009

Idaho National Laboratory

Next Generation Nuclear Plant Project

Idaho Falls, Idaho 83415

Prepared for the

U.S. Department of Energy

Office of Nuclear Energy

Under DOE Idaho Operations Office

Contract DE-AC07-05ID14517 



\section{Next Generation Nuclear Plant Project}

\section{WHITE PAPER \\ Quality Assurance Program Application for the Component Test Capability}

INL/EXT-09-16164

June 2009

Approved by:

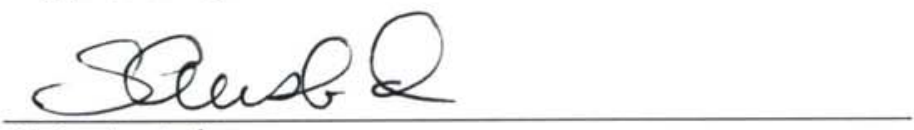

S. L. Austad

F\&SS Project Engineer

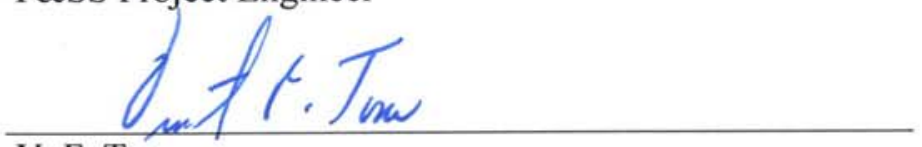

V. F. Tonc

CTC Project Manager
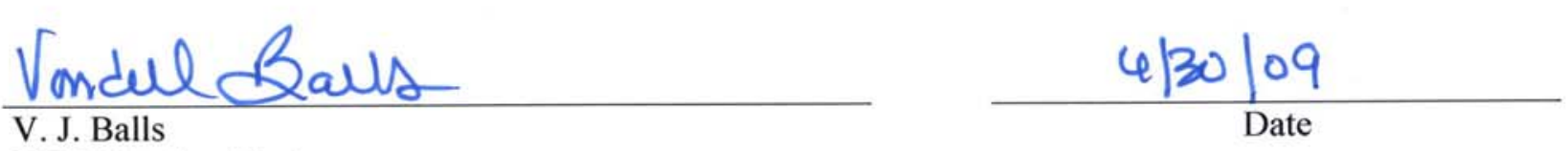

NGNP Project Engineer
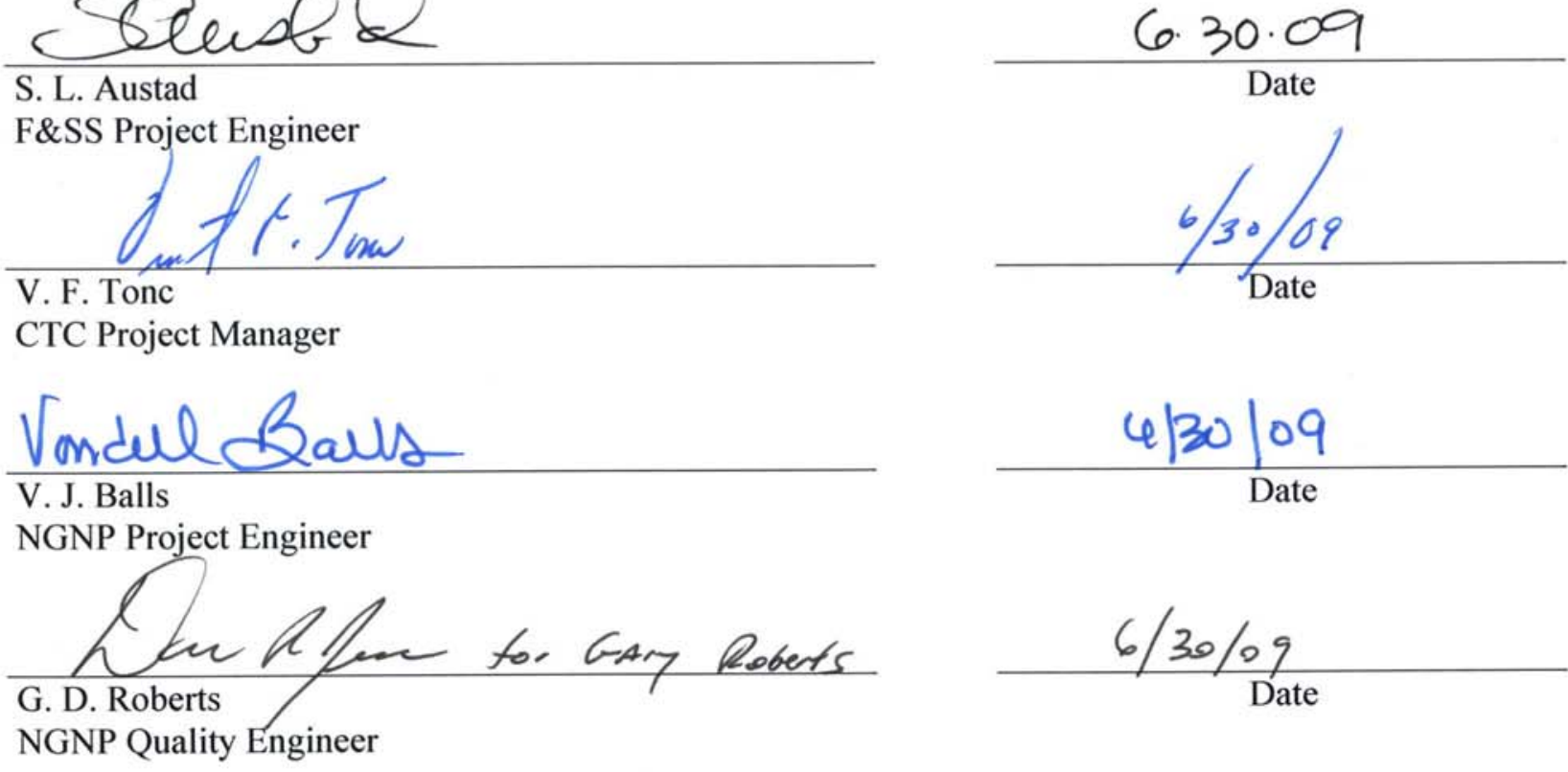

G. D. Roberts

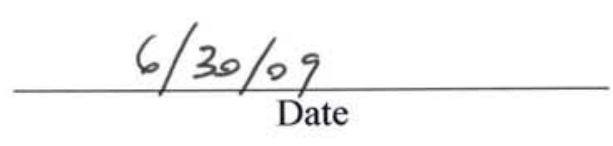





\begin{abstract}
This paper documents the application of quality requirements to Component Test Capability (CTC) Project activities for each CTC alternative. Four alternatives are considered for quality program application: do nothing, vendor testing, existing testing facility modification, and Component Test Facility. It also describes the advantages and disadvantages of using the existing Next Generation Nuclear Plant Quality Program Plan with CTC modifications versus a stand-alone CTC Quality Program Plan.
\end{abstract}




\section{CONTENTS}

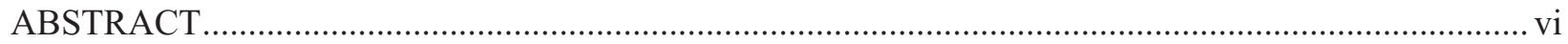

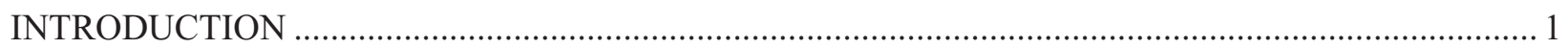

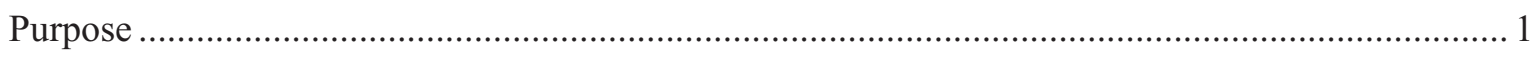

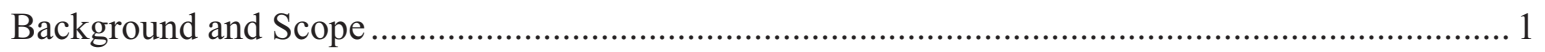

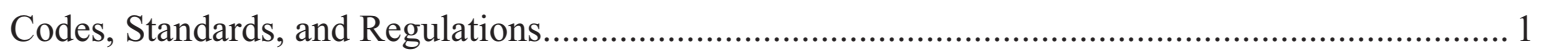

ALTERNATIVE QUALITY PROGRAM APPLICATION …........................................................ 2

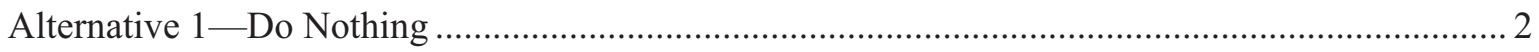

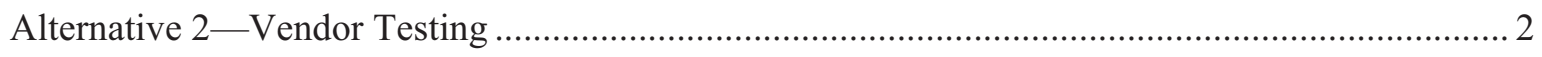

Alternative 3 -Existing Testing Facility Modification............................................................... 3

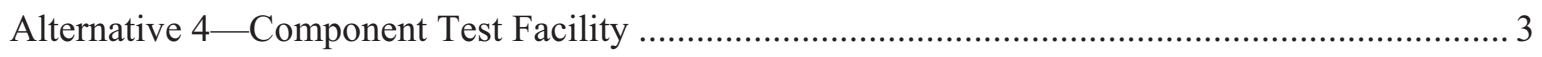

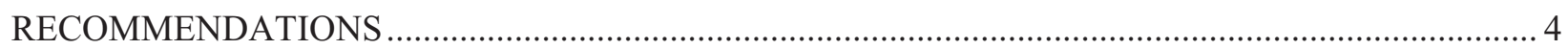




\title{
Quality Assurance Program Application for the Component Test Capability
}

\author{
INTRODUCTION
}

\section{Purpose}

This paper documents the application of quality requirements to Component Test Capability (CTC) Project activities for each CTC alternative. It also describes the advantages and disadvantages of using the existing Next Generation Nuclear Plant (NGNP) Quality Program Plan with CTC modifications versus a stand-alone CTC Quality Program Plan.

DOE G 413.3-2, "Quality Assurance Guide for Project Management," which applies to critical decisions and projects such as the CTC Project, suggests approaches for meeting U.S. Department of Energy (DOE) quality assurance (QA) requirements. As early in the acquisition process as practicable, the project should decide whether to use an existing sitewide QA program or develop a project-specific QA program. This paper will assist in that decision-making process.

\section{Background and Scope}

The alternatives for completing the large-scale integrated testing necessary to validate the interfaces and performance of critical systems and components prior to installation in the VHTR plant include:

1. Do nothing - no large-scale testing of NGNP critical structures, systems, and components (SSCs)

2. Distribute the testing requirements to the component and system vendors as part of the specifications for procurement

3. Modify existing facilities (mostly overseas) to support NGNP large-scale testing needs

4. Construct a stand-alone facility to house and operate test loops designed to meet NGNP large-scale testing needs.

Applying a quality assurance program (QAP) to these alternatives will cover all CTC Project qualityaffecting activities performed by CTC Project personnel (and subcontractors as required by their respective contracts). Quality-affecting activities include those that influence the desired end result, such as: siting, design, procurement, fabrication, construction, operation, handling, shipping, receiving, storing, cleaning, and repairing.

\section{Codes, Standards, and Regulations}

Battelle Energy Alliance (BEA), the management and operating contractor of Idaho National Laboratory (INL), is required to comply with the DOE Idaho Operations Office (DOE-ID) contract (No. DE-AC07-05ID14517). This contract requires BEA to comply with 10 CFR 830 Subpart A and DOE Order 414.1C. NQA -1, "Quality Assurance for Nuclear Facilities," prepared by the American Society of Mechanical Engineers (ASME), is used as the baseline standard for developing and implementing a QAP for INL activities. The INL QAP meets the requirements of 10 CFR 830 Subpart A and DOE Order 414.1C. The following source documents contain requirements applicable to the QAPdefined scope of work: 


\section{Regulatory Documents}

- 10 CFR 830 Subpart A, "Quality Assurance Requirements"

- DOE Order 413.3A, "Program and Project Management for the Acquisition of Capital Assets"

- DOE Order 414.1C, "Quality Assurance Order"

\section{Commitment Documents}

- ASME NQA-1-2000 Part 1, "Quality Assurance Requirements for Nuclear Facility Applications"

- ASME NQA-1-2000 Subpart 2.7, “Quality Assurance Requirements for Computer Software for Nuclear Facility Applications"

If a program or project has unique or special customer QA requirements not covered in the INL Quality Program or needs to deviate from the company INL QAP, a project-specific quality program plan can be developed to address the special conditions. The NGNP QAP Plan (QAPP) is a project-specific QAPP based on the INL QAP.

\section{ALTERNATIVE QUALITY PROGRAM APPLICATION}

Four alternatives are being considered for quality program application: do nothing, vendor testing, existing testing facility modification, and Component Test Facility.

\section{Alternative 1-Do Nothing}

The do nothing alternative excludes large-scale testing of NGNP critical SSCs except during cold start-up in the plant. The design team designs the components and issues drawings and specifications for fabrication of critical SSCs with little or no technology development testing. The design drawings and specifications will be prepared in accordance with the NGNP Quality Program Plan (PLN-2021). A traditional supplier/owner procurement quality relationship would exist with NGNP Quality personnel in an auditing and oversight role.

\section{Alternative 2-Vendor Testing}

The vendor testing alternative distributes the testing requirements to the component and system vendors as part of the specifications for procurement. Vendors perform material and technology development testing as they deem necessary in order to meet the performance specifications. Vendors then fund any modification or construction of testing capabilities needed to support the development and testing of their SSCs and amortize those costs as part of their bid price.

Since the procurement or performance specifications are part of the overall NGNP plant design and scope, the NGNP Quality Program Plan (PLN-2021) will apply to the design, construction, fabrication, and data collection for the testing, as well as the design and fabrication of the final components and systems. A traditional supplier/owner procurement quality relationship would exist with NGNP quality personnel in an auditing and oversight role. 


\section{Alternative 3-Existing Testing Facility Modification}

The existing testing facility modification alternative may have different quality program requirements, depending on the definition of the alternative. This alternative could be applied in several different ways with vastly different contracting strategies and quality requirement applications that include:

- Procuring testing services from an existing non-DOE-owned user-facility such as the PBMR facility in South Africa. In this case, the existing NGNP Quality Program Plan would apply to the procurement of the testing service and data deliverables. This case was previously tested when NGNP Research and Development performed testing at university facilities using the NGNP Quality Program Plan. The plan proved flexible and robust enough to cover the scope of the upgrade of university facilities to perform the testing and testing operations and to generate and validate the test data.

- A strategy where DOE is a partner or leaser in an upgraded user-facility and retains some ownership of the capital investment would require the application of the DOE quality requirements to the design, procurement, construction, and operation aspects of the facility upgrade. However, depending on the location of the user-facility, local quality consensus codes may be preferred over the quality codes specified in the NGNP QAPP. A stand-alone program plan may be required to incorporate the locally recognized codes and standards and QA consensus codes.

\section{Alternative 4-Component Test Facility}

The alternative to construct a stand-alone Component Test Facility (CTF) as a DOE-owned userfacility would require the project elements to comply with the DOE QA requirements. The NGNP Quality Assurance Plan would be consistent with the quality requirements necessary for DOE compliance, NGNP design, and NRC licensing data quality. Deviations to the NGNP QAPP specific to CTF could be addressed in the NGNP QAPP. The advantages of using the NGNP QAPP versus a CTC stand-alone QAPP include current DOE familiarity with the document and program, an existing training infrastructure, and quality resources familiar with the program. Should the NGNP and CTC become separated, the NGNP QAPP could be rewritten as a stand-alone CTC QAPP with little effort. 


\section{RECOMMENDATIONS}

The recommendations of this white paper for each of the alternatives are summarized in Figure 1.

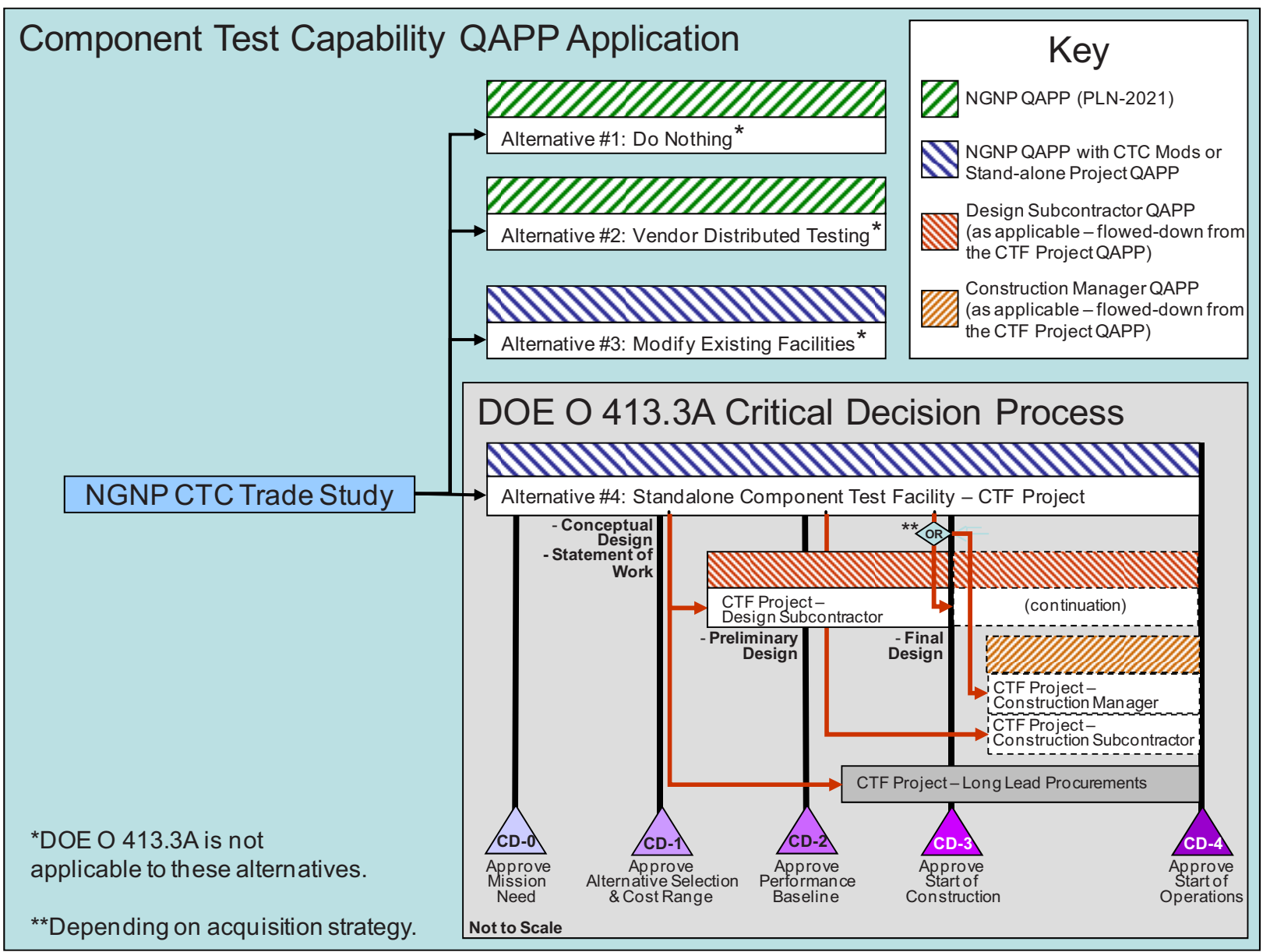

Figure 1. Application of QAPP to Component Test Capability. 